\title{
Feeding nitrate and docosahexaenoic acid affects enteric methane production and milk fatty acid composition in lactating dairy cows
}

\author{
G. Klop, ${ }^{* 1}$ B. Hatew, ${ }^{*}$ A. Bannink, $†$ and J. Dijkstra* \\ ${ }^{*}$ Animal Nutrition Group, Wageningen University, PO Box 338, 6700 AH Wageningen, the Netherlands \\ †Wageningen UR Livestock Research, PO Box 338, 6700 AH Wageningen, the Netherlands
}

\begin{abstract}
An experiment was conducted to study potential interaction between the effects of feeding nitrate and docosahexaenoic acid (DHA; C22:6 n-3) on enteric $\mathrm{CH}_{4}$ production and performance of lactating dairy cows. Twenty-eight lactating Holstein dairy cows were grouped into 7 blocks of 4 cows. Within blocks, cows were randomly assigned to 1 of 4 treatments: control (CON; urea as alternative nonprotein $\mathrm{N}$ source to nitrate), $\mathrm{NO}_{3}[21 \mathrm{~g}$ of nitrate $/ \mathrm{kg}$ of dry matter (DM)], DHA (3 $\mathrm{g}$ of DHA $/ \mathrm{kg}$ of DM and urea as alternative nonprotein $\mathrm{N}$ source to nitrate), or $\mathrm{NO}_{3}+$ DHA (21 g of nitrate $/ \mathrm{kg}$ of DM and $3 \mathrm{~g}$ of DHA $/ \mathrm{kg}$ of DM, respectively). Cows were fed a total mixed ration consisting of $21 \%$ grass silage, $49 \%$ corn silage, and $30 \%$ concentrates on a DM basis. Feed additives were included in the concentrates. Cows assigned to a treatment including nitrate were gradually adapted to the treatment dose of nitrate over a period of $21 \mathrm{~d}$ during which no DHA was fed. The experimental period lasted $17 \mathrm{~d}$, and $\mathrm{CH}_{4}$ production was measured during the last $5 \mathrm{~d}$ in climate respiration chambers. Cows produced on average 363, 263, 369, and $298 \mathrm{~g}$ of $\mathrm{CH}_{4} / \mathrm{d}$ on $\mathrm{CON}, \mathrm{NO}_{3}, \mathrm{DHA}$, and $\mathrm{NO}_{3}+$ DHA treatments, respectively, and a tendency for a nitrate $\times$ DHA interaction effect was found where the $\mathrm{CH}_{4}$-mitigating effect of nitrate decreased when combined with DHA. This tendency was not obtained for $\mathrm{CH}_{4}$ production relative to dry matter intake (DMI) or to fat- and protein corrected milk (FPCM). The $\mathrm{NO}_{3}$ treatment decreased $\mathrm{CH}_{4}$ production irrespective of the unit in which it was expressed, whereas DHA did not affect $\mathrm{CH}_{4}$ production per kilogram of DMI, but resulted in a higher $\mathrm{CH}_{4}$ production per kilogram of fat- and protein-corrected milk (FPCM) production. The FPCM production $(27.9,24.7,24.2$, and $23.8 \mathrm{~kg} / \mathrm{d}$ for CON, $\mathrm{NO}_{3}, \mathrm{DHA}$, and $\mathrm{NO}_{3}+\mathrm{DHA}$, respectively) was lower for DHA-fed cows because of decreased milk
\end{abstract}

Received August 4, 2015.

Accepted October 3, 2015.

${ }^{1}$ Corresponding author: geronda.klop@wur.nl fat concentration. The proportion of saturated fatty acids in milk fat was decreased by DHA, and the proportion of polyunsaturated fatty acids was increased by both nitrate and DHA. Milk protein concentration was lower for nitrate-fed cows. In conclusion, nitrate but not DHA decreased enteric $\mathrm{CH}_{4}$ production and no interaction effects were found on $\mathrm{CH}_{4}$ production per kilogram of DMI or per kilogram of FPCM.

Key words: methane, nitrate, docosahexaenoic acid, milk fatty acid

\section{INTRODUCTION}

Enteric $\mathrm{CH}_{4}$ production in ruminants has received global interest (Hristov et al., 2013), and various feed additives have been suggested as a nutritional mitigation strategy. Feeding nitrate as alternative electron receptor effectively decreases $\mathrm{CH}_{4}$ production in sheep (van Zijderveld et al., 2010), and a persistent effect was shown in lactating dairy cows (van Zijderveld et al., 2011). A sudden inclusion of high concentrations of nitrate in ruminant diets may result in a condition known as methemoglobinemia, which decreases the oxygen carrying capacity of the blood. Symptoms of nitrate toxicity depend on the level of methemoglobin in the blood and may include reduced intake and performance, brown discoloration of mucosae, and even death (Bruning-Fann and Kaneene, 1993). When animals are gradually adapted to higher concentrations of nitrate in their diets, no signs of (sub)clinical methemoglobinemia were observed (van Zijderveld et al., 2010, 2011; Lee and Beauchemin, 2014).

Supplementation of fat to ruminant diets also lowers $\mathrm{CH}_{4}$ production (Grainger and Beauchemin, 2011). Specific fatty acids (FA) have been evaluated for their effect on rumen fermentation, and docosahexaenoic acid (DHA; an n-3 FA; C22:6n-3) has been shown to have a particularly marked effect on microbial metabolism in the rumen (Boeckaert et al., 2008a). Micro-algae enriched in DHA have been shown to decrease $\mathrm{CH}_{4}$ production in vitro (Fievez et al., 2007), but this could not be confirmed in vivo (Moate et al., 2013). 
The VFA profile in rumen fluid may shift toward more acetate when nitrate is fed, whereas DHA may cause a shift toward a larger relative proportion of propionate (Boeckaert et al., 2008b; Guyader et al., 2015). Propionate production is an $\mathrm{H}_{2}$-consuming process and can therefore decrease $\mathrm{CH}_{4}$ production. Because nitrate and DHA have different mechanisms of affecting ruminal methanogenesis, we hypothesize that their effects on $\mathrm{CH}_{4}$ production are additive.

An additive, or positive, interaction effect of the 2 additives would be of interest because it would allow for a similar decrease in $\mathrm{CH}_{4}$ emissions using lower doses of the separate additives. The latter would alleviate the risk of negative effects of the additives on cow health and performance. Moreover, feeding DHA to lactating dairy cows has been reported to increase the proportions of CLA and DHA in milk fat and decrease the SFA proportion (Boeckaert et al., 2008b). From a human health perspective, such an alteration in milk FA composition is of interest (Shingfield et al., 2013). To the best of our knowledge, the effect of feeding nitrate on milk FA profile is unknown.

The main objective of this study was to investigate whether the effects of nitrate and $\mathrm{DHA}$ on $\mathrm{CH}_{4}$ production and animal performance in lactating dairy cows are additive or not. Milk FA profile is a potential indicator of $\mathrm{CH}_{4}$ production (van Lingen et al., 2014), and therefore the effects of nitrate and DHA fed alone or in combination on milk FA composition were also evaluated.

\section{MATERIALS AND METHODS}

\section{Experimental Design, Animals, and Housing}

All experimental procedures were approved by the Animal Care and Use Committee of Wageningen University (Wageningen, the Netherlands). The experiment was set up as a completely randomized block design with 4 treatments. Eight primiparous and 20 multiparous lactating Holstein cows $(125 \pm 16$ DIM at the start of the experimental period; mean $\pm \mathrm{SD}$ ) were blocked according to parity, lactation stage, milk production and presence or absence of a previously fitted rumen cannula. Within blocks, animals were randomly assigned to 1 of the 4 experimental diets. One of the 8 cows with a rumen cannula had to be culled because of foot injuries and was replaced by a nonfistulated reserve animal already adapted to the same experimental $\operatorname{diet}\left(\mathrm{NO}_{3}\right)$.

Animals were housed in a freestall barn from which blocks of 4 cows consecutively entered a 17-d experimental period. This $17-\mathrm{d}$ period consisted of $12 \mathrm{~d}$ in tie-stalls, and from $1500 \mathrm{~h}$ on d 13 until $0900 \mathrm{~h}$ on d
17 , cows were housed individually in climate respiration chambers (CRC).

\section{Diets and Feeding}

The experimental diets consisted of $49 \%$ corn silage, $21 \%$ grass silage, and $30 \%$ concentrates on a DM basis. Treatments consisted of a control treatment (CON; no nitrate or DHA added), a nitrate treatment $\left(\mathbf{N O}_{3} ; 21 \mathrm{~g}\right.$ of nitrate $/ \mathrm{kg}$ of total DM), a DHA treatment (DHA; 3 $\mathrm{g}$ of DHA $/ \mathrm{kg}$ of total $\mathrm{DM}$ ), and a treatment including both nitrate and DHA in the $\operatorname{diet}\left(\mathbf{N O}_{3}+\mathbf{D H A} ; 21 \mathrm{~g}\right.$ of nitrate $/ \mathrm{kg}$ of total $\mathrm{DM}$ and $3 \mathrm{~g}$ of DHA $/ \mathrm{kg}$ of total DM). Nitrate, DHA, or both were included in the concentrates (Table 1). Diets were balanced for $\mathrm{N}$ content by isonitrogenous exchange of nitrate and urea. Cellulose and limestone were added to balance DM and Ca content of the concentrate mixtures. DHAgold (DSM Nutritional Products, Columbia, MD) was exchanged against wheat because of the similar $\mathrm{CP}$ content. The chemical composition of DHAgold was described by Boeckaert et al. (2007) where the DHA content was $198 \mathrm{~g} / \mathrm{kg}$ of DM. In the present study, DHA content of DHAgold was $254 \mathrm{~g} / \mathrm{kg}$ of DM. Chromium oxide (1.7 g/ $\mathrm{kg}$ of DM) was included in all concentrates to estimate total-tract diet digestibility of energy and nutrients. Diets were offered to the cows as TMR (Table 2). Drinking water was continuously available during the entire experiment.

All animals that were assigned to either the $\mathrm{NO}_{3}$ or the $\mathrm{NO}_{3}+$ DHA treatment, including 2 reserve animals, were gradually adapted to the experimental level of dietary nitrate $(21 \mathrm{~g} / \mathrm{kg}$ of $\mathrm{DM})$ over a period of $21 \mathrm{~d}$. Cows were group-fed once daily around $0900 \mathrm{~h}$ and received $25 \%$ of the experimental dose of dietary nitrate during the first week, followed by incremental steps of $25 \%$ per week and thereafter all cows received the full experimental dose of dietary nitrate. No DHA was fed during this period of adaptation to increasing levels of dietary nitrate.

During the experimental periods, cows were fed individually with 2 equal portions offered twice daily (at 0600 and $1600 \mathrm{~h}$ ). A mixture of grass silage and corn silage was prepared twice weekly and weighed into crates that were stored in a cooling room $\left( \pm 7^{\circ} \mathrm{C}\right)$. The concentrates were in meal form and weighed separately into buckets and manually mixed into the roughage mixture at the moment of feeding. Until d 9 of the tie-stall period, each block of cows had free access to feed. Thereafter, DMI within a block was restricted to $95 \%$ of that of the animal with the lowest voluntary DMI between $\mathrm{d} 5$ and 8 , while ensuring that none of the animals in the block was restricted to less than $80 \%$ of its voluntary DMI. 
Table 1. Ingredient composition $(\mathrm{g} / \mathrm{kg}$ of $\mathrm{DM})$ of the experimental concentrates containing no treatment additive $(\mathrm{CON})$, nitrate $\left(\mathrm{NO}_{3}\right)$, docosahexaenoic acid (DHA), or $\mathrm{NO}_{3}+\mathrm{DHA}$ as feed additives

\begin{tabular}{|c|c|c|c|c|}
\hline Ingredient & $\mathrm{CON}$ & $\mathrm{NO}_{3}$ & DHA & $\mathrm{NO}_{3}+\mathrm{DHA}$ \\
\hline Wheat & 194 & 194 & 155 & 155 \\
\hline Dry, ground corn & 145 & 145 & 145 & 145 \\
\hline Beet pulp & 165 & 165 & 165 & 165 \\
\hline Formaldehyde-treated soybean meal & 321 & 321 & 321 & 321 \\
\hline Molasses & 33 & 33 & 33 & 33 \\
\hline Trace mineral and vitamin premix & 9 & 9 & 9 & 9 \\
\hline Monocalcium phosphate & 17 & 17 & 17 & 17 \\
\hline $\mathrm{NaCl}$ & 17 & 17 & 17 & 17 \\
\hline $\mathrm{CaCO}_{3}$ & 57 & - & 57 & - \\
\hline Nitrate source ${ }^{1}$ & - & 98 & - & 98 \\
\hline Urea & 39 & - & 39 & - \\
\hline DHAgold $^{2}$ & - & - & 39 & 39 \\
\hline Cellulose & 2 & - & 2 & - \\
\hline $\mathrm{Cr}_{2} \mathrm{O}_{3}$ & 1.7 & 1.7 & 1.7 & 1.7 \\
\hline
\end{tabular}

\section{Measurements, Sampling, and Laboratory Analyses}

Methane was measured in CRC with a volume of 35 $\mathrm{m}^{3}$ (for details of CRC, see van Gastelen et al., 2015). Briefly, temperature in the chambers was set at $16^{\circ} \mathrm{C}$ and the relative humidity was maintained at $65 \%$. The ventilation rate was $43 \mathrm{~m}^{3} / \mathrm{h}$ per chamber, inlet and exhaust air of each compartment was sampled at 10min intervals, and the light schedule allowed for $16 \mathrm{~h}$ of light per d, starting from $0530 \mathrm{~h}$ onward. Concentrations of $\mathrm{CH}_{4}, \mathrm{O}_{2}$, and $\mathrm{CO}_{2}$ in inlet and exhaust air of each compartment were sampled, and ventilation rates were corrected for air pressure, temperature, and humidity to arrive at standard temperature pressure dew point volumes of inlet and exhaust air. Heat production rates were calculated from gaseous exchange (Brouwer, 1965). Cows were weighed immediately after entering and just before leaving the CRC.

Representative samples of all individual TMR components were collected at the moments of feed preparation for measurement periods in the CRC. Orts were collected during the period that cows were in the CRC. If the amount composed more than $4 \%$ of the estimated DM supply, a representative subsample was analyzed for DM and ash content. If the amount was less than $4 \%$ of DM supply, composition of the orts was assumed to be similar to the composition of the offered diet. During CRC periods, the total amount of manure was

Table 2. Average analyzed chemical composition of TMR ingredients (corn silage, grass silage, and concentrates) and calculated composition of complete TMR for the control (CON) diet and diets with nitrate $\left(\mathrm{NO}_{3}\right)$, docosahexaenoic acid (DHA), or $\mathrm{NO}_{3}+\mathrm{DHA}$ as feed additives $(\mathrm{g} /$ $\mathrm{kg}$ of DM unless otherwise stated)

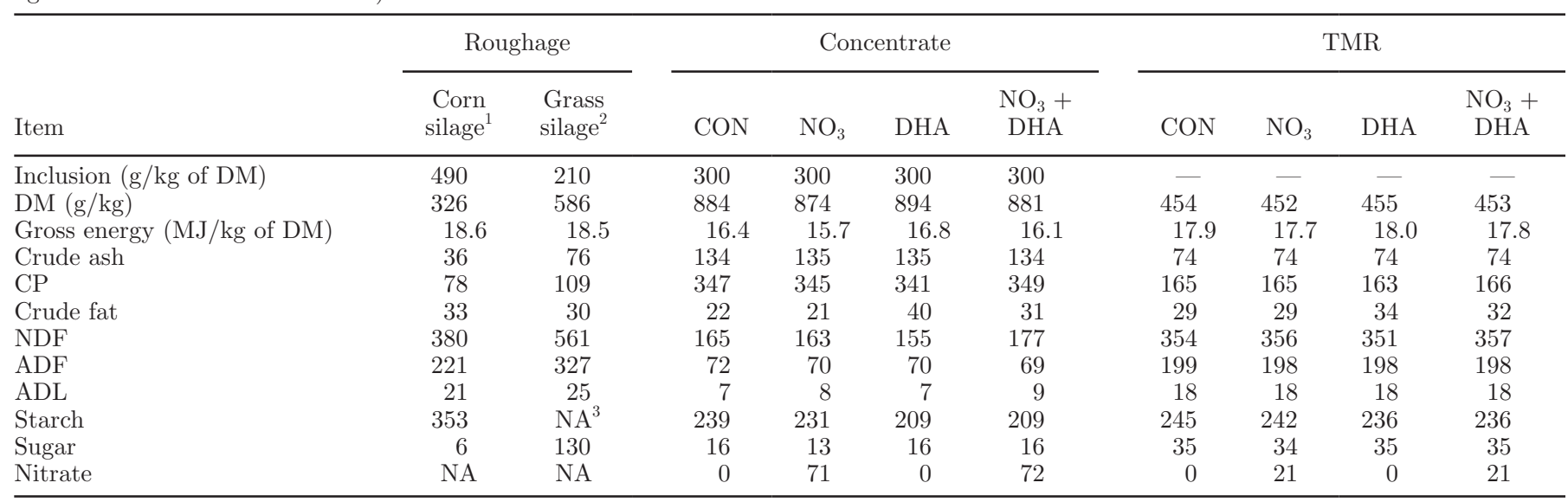

${ }^{1} \mathrm{NE}_{\mathrm{L}}=6.2 \mathrm{MJ} / \mathrm{kg}$ of DM.

${ }^{2} \mathrm{NE}_{\mathrm{L}}=6.9 \mathrm{MJ} / \mathrm{kg}$ of DM.

${ }^{3} \mathrm{NA}=$ not analyzed. 
collected and mixed, and a representative subsample was taken for analysis of DM, gross energy (GE), and $\mathrm{N}$ content. Fecal grab samples were collected at each milking in the CRC for analysis of DM, GE, N, crude fat, starch, NDF, ash, and chromium content to estimate apparent total-tract digestibility of nutrients. Samples were stored at $-20^{\circ} \mathrm{C}$ pending analysis. After thawing, samples were dried at $60^{\circ} \mathrm{C}$ until constant weight and ground to pass a 1-mm screen. The $\mathrm{N}$ concentrations in manure and of roughages were determined in fresh material. For the determination of $\mathrm{NH}_{3}$ content, fresh silage samples were deproteinized by the addition of $10 \%$ (wt/vol) trichloroacetic acid solution followed by centrifugation. Subsequently, indophenol blue was formed using the Berthelot reaction with phenol and hypochlorite in an alkaline solution, which was determined spectroscopically at $623 \mathrm{~nm}$. The DM content of air dry samples was gravimetrically determined by drying at $103^{\circ} \mathrm{C}$ until constant weight (ISO 6496; ISO, $1999 \mathrm{~b})$. Ash was determined after combustion at $550^{\circ} \mathrm{C}$ (ISO 5984; ISO, 2002). Crude protein content was calculated as $\mathrm{N} \times 6.25$, where $\mathrm{N}$ was determined using the Kjeldahl method with $\mathrm{CuSO}_{4}$ as catalyst (ISO 5983; ISO, 2005). Based on findings of Guo et al. (2007), N content of nitrate containing concentrates was corrected assuming a nitrate- $\mathrm{N}$ recovery of $53 \%$ after Kjeldahl analysis. The nitrate concentrations in all concentrates were analyzed at the Eurofins laboratory (Barendrecht, the Netherlands). Briefly, nitrate was extracted from the feed using Milli-Q water and converted into nitrite using a cadmium/copper column. Subsequently, the reaction product formed after combination of nitrite and sulfanilamide in an acidic environment was combined with $\mathrm{N}$-1-naphtylethylene diamine dihydrochloride into a red/purple color, which was measured spectrophotometrically at $550 \mathrm{~nm}$. Nitrite concentration of the original sample was analyzed separately to correct the result for nitrate. Hydrolysis with $\mathrm{HCl}$ and extraction with light petroleum was used to determine crude fat content of samples (ISO 6492; ISO, 1999a). Starch was determined enzymatically (ISO 15914; ISO, 2004). The NDF content of samples was analyzed according to Van Soest et al. (1991) after pretreatment with $\alpha$-amylase, but without sodium sulfite. Methods described by Van Soest et al. (1991) were also used for analysis of ADF content and ADL was analyzed using sulfuric acid (Robertson and Van Soest, 1981). An adiabatic bomb calorimeter (IKA-C700, Janke and Kunkel, Heitersheim, Germany) was used for determination of GE content (ISO 9831; ISO, 1998). Chromium contents of concentrates and feces were analyzed using atomic absorption spectrophotometry (Williams et al., 1962).

Milk Production and Milk Composition. Cows were milked twice daily (0600 and $1600 \mathrm{~h}$ ) throughout the entire experiment. Milk production was recorded at each milking. A subsample of milk from each milking in the CRC was analyzed for fat, protein, lactose, and GE, and $\mathrm{N}$ and MUN content were analyzed in a pooled sample from all milkings in the CRC $(5 \mathrm{~g} / \mathrm{kg}$ of milk produced) according to methods described by Hatew et al. (2015a). Average milk composition for each cow was calculated from the weighted average of all samples taken during the 72-h measurement period in the CRC. Fat- and protein-corrected milk yield (FPCM) was calculated according to the formula FPCM $(\mathrm{kg} / \mathrm{d})=$ $(0.337+0.116 \times$ fat $\%+0.06 \times$ protein $\%) \times$ milk yield (kg/d) (CVB, 2008). For each cow, an additional milk sample was collected $(5 \mathrm{~g} / \mathrm{kg}$ of milk at each milking in the chambers) and analyzed for milk FA composition through gas chromatography as described by van Gastelen et al. (2015). Milk FA were expressed in grams per $100 \mathrm{~g}$ of total FA.

Blood Samples. During the 21 d of pre-experimental period of adaptation to the final inclusion level of dietary nitrate, a blood sample was collected from all 16 cows fed nitrate after each incremental dose of nitrate in the diet (i.e., d 1, 7, 14, and 21 of this preexperimental period). Blood was collected from the tail vein in heparinized collection tubes at $3 \mathrm{~h}$ postfeeding. Blood samples were analyzed for hemoglobin $(\mathbf{H b})$ and methemoglobin (MetHb) content within $1.5 \mathrm{~h}$ after sampling in the laboratory of Hospital Gelderse Vallei (Ede, the Netherlands) using a blood gas analyzer ABL-825 (Radiometer, Copenhagen, Denmark).

\section{Statistical Analysis}

Data on DMI, milk production, milk composition, and $\mathrm{CH}_{4}$ production are based on measurements during the last $72 \mathrm{~h}$ of the measurement period when cows were in the CRC. For one cow (DHA treatment) only the last $48 \mathrm{~h}$ of the measurement period were used, because this cow had an extremely low DMI and water intake during the first $24 \mathrm{~h}$ of the measurement period. Two cows (CON and $\mathrm{NO}_{3}$ treatment) were excluded from the analyses because of a feeding error in the CRC. Energy and N retention and digestibility values were calculated based on the entire period in the CRC and averaged per day. For milk FA composition, values below the detection limit $(<0.02 \mathrm{~g} / 100 \mathrm{~g}$ of FA) were considered missing values.

All data were analyzed using PROC MIXED (SAS 9.2, SAS Inst. Inc., Cary, NC). The model contained main and interaction effects of dietary treatment factors (nitrate and DHA) as fixed effects and the effect of period (which is equal to block) as a random factor using a variance components (VC) covariance structure. The effect of chamber was initially included as fixed 
effect in the model, but was removed because it was not significant. Denominator degrees of freedom were estimated using the Kenward-Roger option. Multiple comparisons between treatments were made using the Tukey-Kramer method. Results are reported as least squares means, and significance of effects was declared at $P \leq 0.05$ and trends at $0.05<P \leq 0.10$.

\section{RESULTS AND DISCUSSION}

\section{Methane Production and Cow Performance}

The main objective of this study was to examine if the effects of dietary nitrate and DHA on enteric $\mathrm{CH}_{4}$ production of lactating dairy cows are additive. For $\mathrm{CH}_{4}$ production in grams per day, a tendency for a nitrate $\times$ DHA interaction was found (Table 3), showing that the effect of nitrate and DHA is different when combined. This was most likely a result of the lower DMI of cows receiving the $\mathrm{NO}_{3}$ treatment, despite the restricted feeding regimen. Nevertheless, if DMI would have been equal across all treatments, the $\mathrm{CH}_{4}$ production per kilogram of DMI might have been slightly higher for cows on the $\mathrm{NO}_{3}$ treatment, but not to such an extent that it would have altered the overall conclusions of this experiment because the feed intake of the $\mathrm{NO}_{3}$ treatment is still $\sim 95 \%$ of the intake of the other treatments. Decreased feed intake after feeding dietary nitrate to ruminant animals has been reported previously (Newbold et al., 2014; Lee et al., 2015b).
With $\mathrm{CH}_{4}$ production expressed in grams per kilogram of DMI or grams per kilogram of FPCM, the nitrate $\times$ DHA interaction term was not significant, showing an additive effect between nitrate and DHA. Nitrate decreased $\mathrm{CH}_{4}$ irrespective of the unit in which it was expressed, whereas DHA had no effect on $\mathrm{CH}_{4}$ per kilogram of DMI or $\mathrm{CH}_{4}$ per kilogram of digestible OM intake, but resulted in a higher $\mathrm{CH}_{4}$ production per kilogram of FPCM (Table 3). Moate et al. (2013) reported increased $\mathrm{CH}_{4}$ emissions per kilogram of DMI and per kilogram of ECM in response to increasing levels of DHA in the diet. Cows in the study of Moate et al. (2013) had unrestricted access to roughage, whereas in the present experiment a restricted feeding regimen was applied. The latter may explain the absence of an effect of DHA on DMI in the present study, whereas in the study of Moate et al. (2013), DMI was significantly reduced at higher doses of DHA $(22.1,22.4,21.3$, and $20.5 \mathrm{~kg}$ of $\mathrm{DMI} / \mathrm{d}$ for the treatments receiving 0 , 25 , 50, or $75 \mathrm{~g}$ of $\mathrm{DHA} / \mathrm{d}$, respectively). Previously, DHA has been found to reduce $\mathrm{CH}_{4}$ production in vitro (Fievez et al., 2007), but this reduction could not be confirmed in vivo by Moate et al. (2013) and in the present trial. Hatew et al. (2015b) showed that effects of starch source and level on in vitro $\mathrm{CH}_{4}$ production were not observed in vivo in animals adapted to the various starch sources and levels when $\mathrm{CH}_{4}$ production was expressed per unit of OM intake. We hypothesize that in the present trial the rumen microbial ecosystem adapted to DHA supply resulting in unchanged

Table 3. Dry matter intake, milk production, milk composition, and $\mathrm{CH}_{4}$ production of dairy cattle fed the control (CON) diet or diets with nitrate $\left(\mathrm{NO}_{3}\right)$, docosahexaenoic acid (DHA), or $\mathrm{NO}_{3}+$ DHA as feed additives

\begin{tabular}{|c|c|c|c|c|c|c|c|c|}
\hline \multirow[b]{2}{*}{ Item } & \multicolumn{4}{|c|}{ Treatment $^{1}$} & \multirow[b]{2}{*}{ SEM } & \multicolumn{3}{|c|}{$P$-value } \\
\hline & $\mathrm{CON}$ & $\mathrm{NO}_{3}$ & DHA & $\mathrm{NO}_{3}+\mathrm{DHA}$ & & $\mathrm{NO}_{3}$ & DHA & $\mathrm{NO}_{3} \times \mathrm{DHA}$ \\
\hline Milk production $(\mathrm{kg} / \mathrm{d})$ & 27.8 & 25.1 & 28.0 & 28.0 & 1.64 & 0.201 & 0.180 & 0.228 \\
\hline $\mathrm{FPCM}^{2}(\mathrm{~kg} / \mathrm{d})$ & 27.9 & 24.7 & 24.2 & 23.8 & 1.58 & 0.128 & 0.062 & 0.233 \\
\hline Fat $(\mathrm{g} / \mathrm{kg})$ & 40.9 & 39.5 & 29.8 & 29.4 & 2.12 & 0.602 & $<0.001$ & 0.744 \\
\hline Fat $(\mathrm{g} / \mathrm{d})$ & 1,147 & 1,008 & 824 & 814 & 76.4 & 0.231 & $<0.001$ & 0.296 \\
\hline Lactose (g/kg) & 44.8 & 45.6 & 46.6 & 46.2 & 0.69 & 0.728 & 0.043 & 0.281 \\
\hline MUN (mg/dL) & 11.4 & 11.4 & 13.1 & 11.2 & 0.88 & 0.288 & 0.393 & 0.311 \\
\hline $\mathrm{CH}_{4}(\mathrm{~g} / \mathrm{d})$ & 363 & 263 & 369 & 298 & 14.5 & $<0.001$ & 0.016 & 0.069 \\
\hline $\mathrm{CH}_{4}(\mathrm{~g} / \mathrm{kg}$ of $\mathrm{DMI})$ & 22.0 & 16.9 & 22.4 & 18.2 & 0.52 & $<0.001$ & 0.086 & 0.305 \\
\hline $\mathrm{CH}_{4}\left(\mathrm{~g} / \mathrm{kg}\right.$ of $\left.\mathrm{DOMI}^{3}\right)$ & 31.4 & 24.7 & 31.9 & 25.5 & 0.69 & $<0.001$ & 0.352 & 0.759 \\
\hline $\mathrm{CH}_{4}(\mathrm{~g} / \mathrm{kg}$ of $\mathrm{FPCM})$ & 13.1 & 10.8 & 15.4 & 12.6 & 0.57 & $<0.001$ & 0.001 & 0.629 \\
\hline $\mathrm{CH}_{4}\left(\%\right.$ of $\left.\mathrm{GEI}^{4}\right)$ & 6.8 & 5.3 & 7.0 & 5.7 & 0.35 & $<0.001$ & 0.090 & 0.487 \\
\hline
\end{tabular}

${ }^{1} \mathrm{CON}$ (urea as nonprotein $\mathrm{N}$ source), $\mathrm{NO}_{3}(21 \mathrm{~g}$ of nitrate $/ \mathrm{kg}$ of $\mathrm{DM}), \mathrm{DHA}\left(3 \mathrm{~g}\right.$ of DHA $/ \mathrm{kg}$ of DM and urea as nonprotein $\mathrm{N}$ source), $\mathrm{NO}_{3}+$ DHA (21 g of nitrate $/ \mathrm{kg}$ of DM and $3 \mathrm{~g}$ of DHA $/ \mathrm{kg}$ of DM). For CON and $\mathrm{NO}_{3}$ treatments $\mathrm{n}=6$, for DHA and $\mathrm{NO}_{3}+\mathrm{DHA}$ treatments $\mathrm{n}=7$. ${ }^{2}$ Fat- and protein-corrected milk $(\mathrm{FPCM})=(0.337+0.116 \times$ fat $\%+0.06 \times$ protein $\%) \times$ milk yield $(\mathrm{kg} / \mathrm{d})(\mathrm{CVB}, 2008)$.

${ }^{3} \mathrm{DOMI}=$ digestible organic matter intake.

${ }^{4} \mathrm{GEI}=$ gross energy intake. 
$\mathrm{CH}_{4}$ production compared with the control. If $21 \mathrm{~g}$ of nitrate/ $\mathrm{kg}$ of DMI is completely reduced to ammonia, $\mathrm{CH}_{4}$ emission should be lowered by $5.4 \mathrm{~g} / \mathrm{kg}$ of DMI based on stoichiometry. With an average $\mathrm{CH}_{4}$ production of 17.6 and $22.2 \mathrm{~g} / \mathrm{kg}$ of DMI for cows receiving a diet with and without nitrate, respectively, the average decline in $\mathrm{CH}_{4}$ reduction corresponds to $85 \%$ of the stoichiometric potential to decrease $\mathrm{CH}_{4}$. This agrees with findings from previous studies in which similar dietary inclusion levels of nitrate were fed to lactating dairy cows (Lund et al., 2014) or beef cattle (Hulshof et al., 2012) and where $\mathrm{CH}_{4}$ production was lowered by $86 \%$ and $87 \%$ of the stoichiometric potential, respectively. The present decrease in $\mathrm{CH}_{4}$ production is higher compared with the study of van Zijderveld et al. (2011), who found a decrease of $59 \%$ of the theoretical potential. The feed intake of cows in the study of van Zijderveld et al. (2011) was higher $( \pm 19 \mathrm{~kg}$ of DMI/d) than the DMI of cows in the current experiment $( \pm 16$ $\mathrm{kg}$ of $\mathrm{DMI} / \mathrm{d}$ ). The lower DMI in the present study may have resulted in a longer retention time of feed or fluid, and of nitrate, in the rumen and thus more time for nitrate to be completely reduced to ammonia. Although this argument seems to be in contrast with findings of Lund et al. (2014), who reported a similar decline in $\mathrm{CH}_{4}$ yield at DMI values above $19 \mathrm{~kg} / \mathrm{d}$ when nitrate was fed, this contrast may be partly explained by the differences in experimental setup. In the study of van Zijderveld et al. (2011) methods of adaptation and feed restriction were similar to the present study, whereas in the study of Lund et al. (2014) no feed restriction was imposed and cows were also not gradually adapted to the experimental level of nitrate in their diet. Such differences in experimental setup may have affected rumen metabolism differently. Moreover, based on visual observations in the tie-stalls, cows receiving any of the additive treatments in the present study also seemed to have a more gradual feed intake pattern than cows on the CON treatment. Based on visual observations of the diurnal patterns of the respiration quotient (RQ; data not included), we noticed that the RQ value showed a sharp increase for the CON treatment shortly after feeding, whereas the other treatments had lower RQ peak values after feeding. This numerical difference supports the visual observations in tie-stalls and CRC that the feed intake pattern was different across treatments. Alteration of feeding behavior as a result of dietary nitrate supplementation has been reported previously for beef calves (Lichtenwalner et al., 1973). Such a difference in feed intake pattern could not be quantified in the present study, but a more gradual feed intake, with smaller portions per meal, may have contributed as well to a longer retention time of nitrate in the rumen. Guyader et al. (2015) fed nitrate (22.5 g/ $\mathrm{kg}$ of DMI) to nonlactating cows with an average DMI of $12.3 \mathrm{~kg} / \mathrm{d}$ and found a decrease in $\mathrm{CH}_{4}$ production of $5.6 \mathrm{~g} / \mathrm{kg}$ of DM compared with the control diet. This corresponds to $96 \%$ of the stoichiometric potential of $5.8 \mathrm{~g} / \mathrm{kg}$ of DM. The difference in physiological state (nonlactating), as well as an increased rumen retention time of nitrate as a result of the lower feed intake in the former study, may explain the larger decrease in $\mathrm{CH}_{4}$ as compared with the present experiment.

Milk production was not affected by dietary treatment, but FPCM production tended to be decreased by DHA as a result of a significantly lower milk fat production (Table 3). Several rumen biohydrogenation intermediates, including trans-10 FA, increase upon feeding DHA, and after absorption such intermediates may decrease de novo FA synthesis in the mammary gland (Boeckaert et al., 2008b). Feeding DHA decreased SFA concentrations (expressed as g/100 g of total FA) in milk and increased concentrations of PUFA (Table 4). The latter is comparable to findings of Boeckaert et al. (2008b) and Moate et al. (2013). To our knowledge, the effect of dietary nitrate on milk FA composition has not yet been reported. Nitrate had no effect on SFA proportion and proportion of MUFA, but increased the proportion of PUFA in milk FA. The proportion of C4:0 in milk FA was increased by feeding nitrate. Unlike other saturated short-chain FA, C4:0 in milk fat does not require acetate for its production as it can be produced directly from $\beta$-hydroxybutyrate derived from the blood. Nitrate also increased the proportion of C18:0 in milk fat (Table 4), which is indicative for more biohydrogenation in the rumen. This may be a consequence of the aforementioned longer retention time of feed in the rumen as compared with cows on the CON treatment. The proportions of C14:0 iso and C15:0 iso were also increased by nitrate, whereas $\mathrm{CH}_{4}$ was decreased. This is in contrast with findings of Castro-Montoya et al. (2011), who reported a positive relationship between iso-FA and $\mathrm{CH}_{4}$ yield. This relationship was associated with the higher abundance of iso-FA in fibrolytic microbes (Vlaeminck et al. 2006), which in turn are associated with a higher $\mathrm{CH}_{4}$ yield. However, feeding nitrate only was observed to decrease total-tract apparent fiber digestion, and the increased levels of C14:0 iso and C15:0 iso in milk fat, indicative of increased abundance of fibrolytic bacteria, are not in line with the reduced fiber digestion observed when feeding nitrate without DHA. The increase in trans-11 FA together with a decline in $\mathrm{CH}_{4}$ production in cows receiving nitrate is in line with van Lingen et al. (2014). In contrast to feeding nitrate, feeding DHA decreased the proportion of C18:0 in milk fat. This agrees qualitatively with in vitro studies with DHA added to rumen fluid of cows adapted to DHA, where 
biohydrogenation of C18:2 trans-11,cis-15 was hindered and no biohydrogenation of C18:1 trans-11 to C18:0 occurred (Vlaeminck et al., 2008). Feeding DHA increased proportions of several MUFA, including C18:1 trans-10 and C18:1 trans-11. The alteration in milk FA profile is in line with findings of Boeckaert et al. (2008b). However, contrary to the present study, these FA are often associated with a decrease in $\mathrm{CH}_{4}$ per unit of feed and per unit of FPCM (van Lingen et al. 2014). If the best performing equations (viz. equations 3 and 4) of van Lingen et al. (2014) are used to predict $\mathrm{CH}_{4} / \mathrm{kg}$ of DMI and $\mathrm{CH}_{4} / \mathrm{kg}$ of FPCM, respectively, from the present milk FA data, a considerable deviation is present between observed and predicted values. Predicted $\mathrm{CH}_{4}$ production is 20.8, 19.9, 12.4, and 14.8 $\mathrm{g} / \mathrm{kg}$ of DMI and 12.1, 11.5, 9.7, and $9.4 \mathrm{~g} / \mathrm{kg}$ of FPCM for the CON, $\mathrm{NO}_{3}, \mathrm{DHA}$, and $\mathrm{NO}_{3}+\mathrm{DHA}$ treatments, respectively. Based on the prediction equations, $\mathrm{CH}_{4}$ production should be decreased by DHA and nitrate would have almost no effect, which is in contrast with the present observations. These comparisons indicate that relationships between $\mathrm{CH}_{4}$ production and milk FA profile, obtained on a wide variety of diets (van Lingen et al. 2014), differ from relationships between $\mathrm{CH}_{4}$ production and milk FA profile when $\mathrm{CH}_{4}$-mitigating supplements such as nitrate and DHA are included in the diet, and thus also limit the general potential of milk FA to predict $\mathrm{CH}_{4}$ production. No DHA was detected in milk from cows receiving the $\mathrm{CON}$ or $\mathrm{NO}_{3}$ treatment. The absence of DHA levels above the detection limit of $0.02 \mathrm{~g} / 100 \mathrm{~g}$ of FA in milk of cows that were not supplemented with DHA corresponds to the findings of van Valenberg et al. (2013), who investigated milk FA composition of representative Dutch bovine milk samples that were collected weekly for a period of $1 \mathrm{yr}$. On average $0.67 \mathrm{~g}$ of DHA/100 g of FA was detected in milk from cows receiving DHA. The DHA content of the TMR $(3 \mathrm{~g} / \mathrm{kg}$ of DM) resulted in a daily intake of almost $50 \mathrm{~g}$ of DHA/cow. This intake is comparable to the $50 \mathrm{~g}$ of DHA/cow (D50) dose fed by Moate et al. (2013) who found a similar amount of 0.60 $\mathrm{g}$ of DHA/100 $\mathrm{g}$ of FA in milk.

Milk protein content was not affected by DHA, but feeding nitrate resulted in a small, but significant reduction in milk protein content and yield (Table 3). Dietary nitrate also resulted in a lower protein concentration in the study of van Zijderveld et al. (2011). However, protein yield was not affected by nitrate in their study in contrast to the present study where protein yield was 796 and $869 \mathrm{~g} / \mathrm{d}$ for diets with or without nitrate, respectively $(P=0.030)$. In the Dutch protein evaluation system (DVE/OEB system), DVE indicates digestible feed and microbial true protein digested in the small intestine (Tamminga et al., 1994).
In the current experiment, the calculated DVE supply based on diet composition exceeded $100 \%$ of the calculated DVE requirements, indicating that supply of protein did not limit milk protein synthesis. Incomplete reduction of dietary nitrate may decrease the amount of rumen-available $\mathrm{N}$ and consequently impair microbial protein synthesis and result in a lower DVE supply than expected based on standard feed values. The resulting lower DVE supply would then negatively affect milk protein yield. However, the actual decline in $\mathrm{CH}_{4}$ production in the current study was rather close to stoichiometric potential of nitrate, which implies that most of the nitrate must have been decreased to ammonia and has contributed to rumen available N. Alternatively, the negative effect of nitrate on milk protein yield may be related to a decreased supply of gluconeogenic precursors. Nitrate has been shown to increase the acetate:propionate ratio in the rumen (Guyader et al., 2015), which could also affect milk protein content. Rigout et al. (2003) reported an experiment and bibliographical study showing a positive linear relationship between the supply of glucogenic precursors and milk protein content. Glucose is an important factor in signaling pathways thought to regulate milk protein synthesis (Rius et al., 2010).

No treatment effects were found for MUN content of milk (Table 3), and values were comparable to those found by van Zijderveld et al. (2011), who fed a similar diet as in the present study.

\section{Blood Methemoglobin}

The average $\mathrm{Hb}$ content $(\mathrm{mmol} / \mathrm{L})$ of blood of the 16 cows that were gradually adapted to increasing levels of dietary nitrate was 5.9 on d 1 and 7 , and 5.6 on d 14 and 21 of the adaptation period before the experimental period. Blood MetHb (\% of total $\mathrm{Hb}$ ) was on average $1.3 \%$ on both $\mathrm{d} 1$ and $\mathrm{d} 7,2.5 \%$ on $\mathrm{d} 14$, and $3.4 \%$ on $\mathrm{d} 21$. The highest MetHb value measured for an individual animal was $11.8 \%$ on $\mathrm{d} 21$. This level is substantially below the level of $30 \%$ that is considered to cause subclinical methemoglobinemia (Bruning-Fann and Kaneene, 1993).

\section{Energy and Nitrogen Retention}

No nitrate $\times$ DHA interaction effects on energy and $\mathrm{N}$ retention were found (Table 5). The MEI:GEI ratio was higher for the diets containing DHA (Table 5). The calculated energy retention was positive for cows receiving DHA and negative for cows on the $\mathrm{CON}$ or $\mathrm{NO}_{3}$ treatment. The tendency for decreased energy output in milk may explain the positive energy retention of the cows receiving DHA. The absence of a significant 
effect of nitrate on FPCM production or milk energy output is in line with results from a recent review by Lee and Beauchemin (2014), who also reported that the consistent decline in $\mathrm{CH}_{4}$ yield by dietary nitrate appears to be without directing additional energy toward animal production.

Table 4. Fatty acid composition of milk from dairy cattle fed the control $(\mathrm{CON})$ diet or diets with nitrate $\left(\mathrm{NO}_{3}\right)$, docosahexaenoic acid $(\mathrm{DHA})$, or $\mathrm{NO}_{3}+$ DHA as feed additives

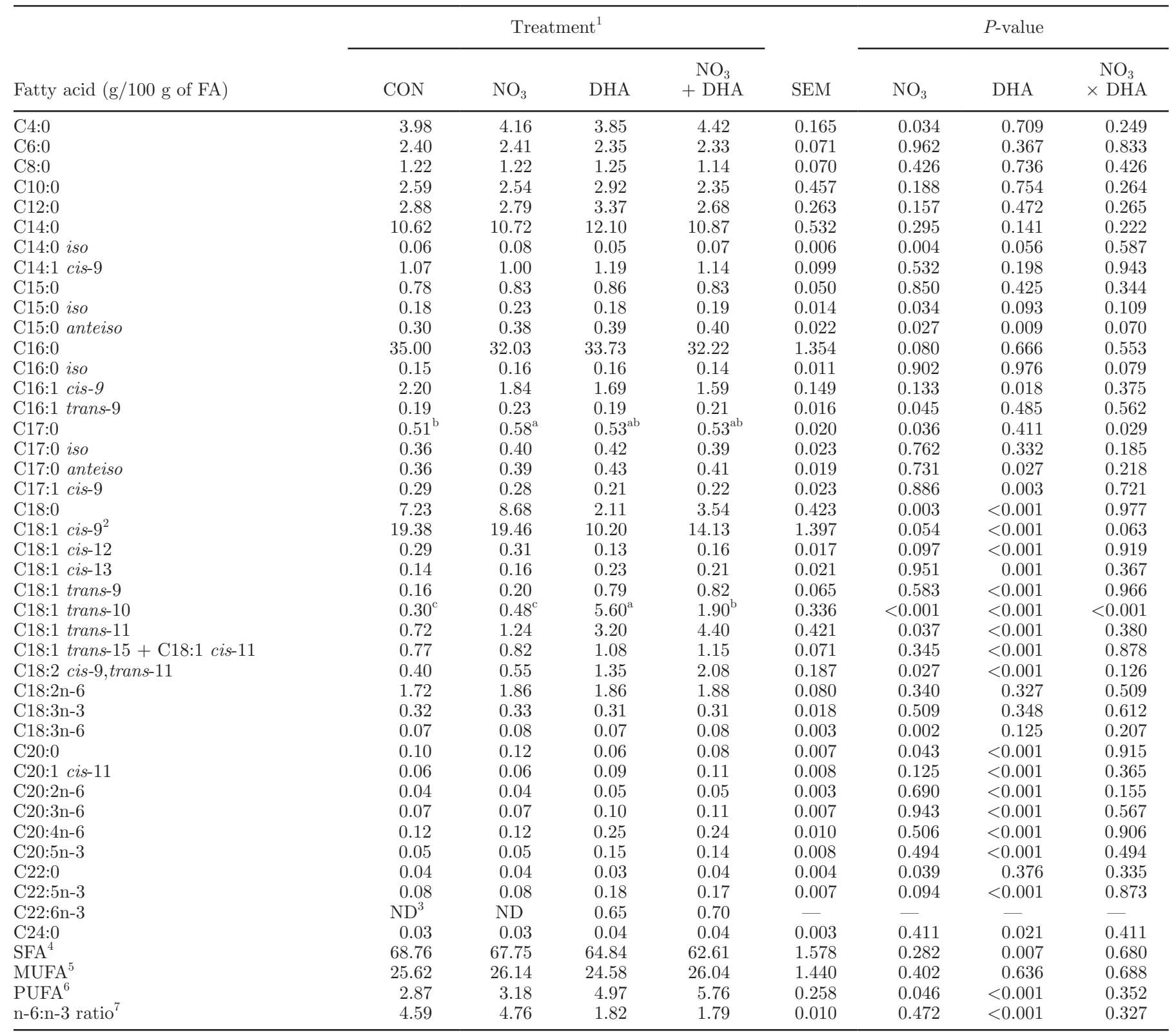

${ }^{\mathrm{a}-\mathrm{c}}$ Means within a row with different superscripts differ $(P<0.05)$.

${ }^{1} \mathrm{CON}$ (urea as nonprotein $\mathrm{N}$ source), $\mathrm{NO}_{3}\left(21 \mathrm{~g}\right.$ of nitrate $/ \mathrm{kg}$ of DM), DHA $\left(3 \mathrm{~g}\right.$ of DHA $/ \mathrm{kg}$ of DM and urea as nonprotein $\mathrm{N}$ source), $\mathrm{NO}_{3}+$

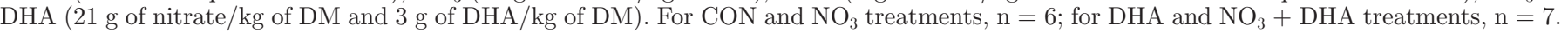
${ }^{2} \mathrm{C} 18: 1$ cis-9 consists of the sum of C18:1 cis-9 and C18:1 trans-12, because these 2 fatty acids could not be separated in the analysis. The proportion of C18:1 trans-12 is usually negligible.

${ }^{3} \mathrm{ND}=$ not detected (detection limit $=0.02 \mathrm{~g} / 100 \mathrm{~g}$ of fatty acids).

${ }^{4} \mathrm{Sum}$ of SFA reported in this table.

${ }^{5}$ Sum of MUFA reported in this table.

${ }^{6}$ Sum of PUFA reported in this table.

${ }^{7}$ Ratio between the sum of C18:2n-6, C18:3n-6, C20:2n-6, C20:3n-6, and C20:4n-6, and the sum of C18:3n-3, C20:5n-3, C22:5n-3, and for treatments DHA and $\mathrm{NO}_{3}+$ DHA also C22:6n-3. 


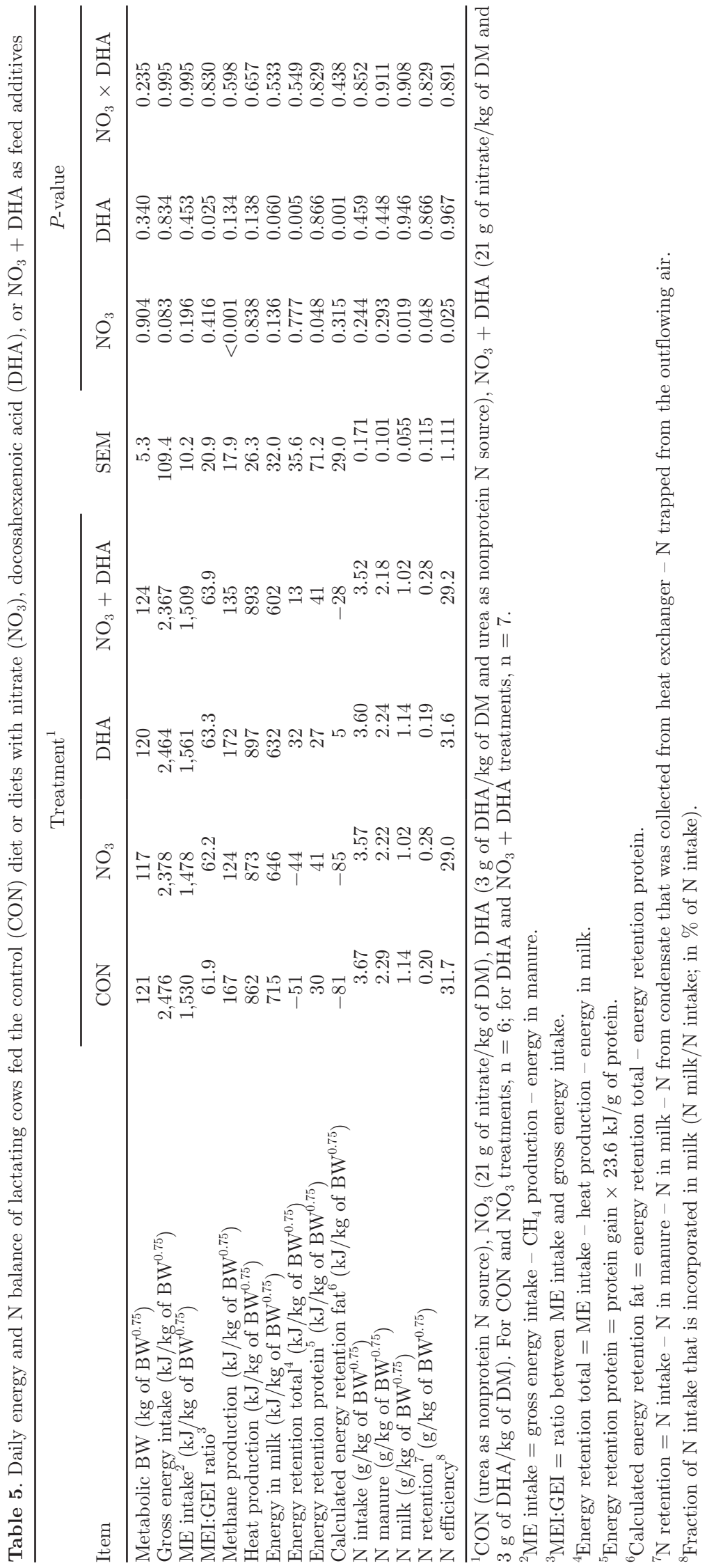


Nitrogen retention was positive for all treatments (Table 5). The average $\mathrm{N}$ retention was $28 \mathrm{~g} / \mathrm{d}$, which is in line with the generally small positive $\mathrm{N}$ retention reported for dairy cattle $\mathrm{N}$ balance trials as reviewed by Spanghero and Kowalski (1997). Intake and excretion of $\mathrm{N}$ was similar among treatments. As expected based on results for milk protein, the $\mathrm{N}$ output in milk and $\mathrm{N}$ efficiency of milk production were lower for cows receiving nitrate (Table 5). Nitrogen retention was significantly higher for cows receiving nitrate, whereas $\mathrm{N}$ in manure was not affected.

\section{Digestibility of Nutrients}

Supplementation of DHA generally resulted in higher total-tract digestibility of various nutrients (Table 6). The higher fat digestibility on treatments with DHA is probably caused by the slight difference in fat content of the TMR with and without DHA (Table 2). If fat supplementation is higher, the calculated digestibility values are less affected by fecal excretion of endogenous fat sources (Kil et al., 2010). This difference in dietary fat content could not be prevented in the experimental set-up as exchanging DHA against another fat source would not allow to distinguish between the effect of fat or a specific FA on $\mathrm{CH}_{4}$ emissions.

Unlike the results for $\mathrm{CH}_{4}$ production, effects of nitrate and DHA on apparent total-tract digestibility of nutrients were often not additive (Table 6). Digestibility of $\mathrm{CP}$ was not different between treatments and does therefore not provide an explanation for the difference in milk protein yield and $\mathrm{N}$ utilization for milk production that was observed between treatments with and without nitrate. Moreover, a reduction in DMI and nutrient digestibility was only found for the $\mathrm{NO}_{3}$ treatment and not for the $\mathrm{NO}_{3}+$ DHA treatment (Table 6 ). The effect of DHA on NDF digestibility and signifi- cance of the interaction term seems mainly to be the result of the low NDF digestibility value obtained for the $\mathrm{NO}_{3}$ treatment (Table 6). The significantly lower NDF digestion may be related to a decreased functioning of cell wall degrading microorganisms as a result of a temporarily increased ruminal concentrations of $\mathrm{H}_{2}$. Such increases in $\mathrm{H}_{2}$ concentration after nitrate supplementation have been reported previously (van Zijderveld et al., 2011; Lund et al., 2014). Accumulation of $\mathrm{H}_{2}$ in the rumen may impair regeneration of $\mathrm{NAD}+$ from NADH (McAllister and Newbold, 2008), and this may negatively affect cell wall degradation by rumen microbes. Nitrite, as intermediate in the reduction of nitrate to ammonia, decreased in vitro cell wall digestion and inhibited growth of cellulolytic bacteria (Marais et al., 1988) and may also have negatively affected NDF digestibility. However, the MetHb concentrations in blood of cows receiving nitrate were relatively low in the present study, and it is thus less likely that nitrite accumulated to substantial amounts in the rumen. Nevertheless, a possible negative effect of nitrite on fiber digestion cannot be excluded.

The findings of Lee et al. (2015b) suggest that a restricted feeding regimen influences the potential adverse effects of nitrate on animal health and performance. Despite the poor palatability of nitrate, cows may consume relatively large amounts of nitrate in one meal under restricted feeding, which may exert negative effects in the rumen. Lee et al. (2015a) observed no effect of nitrate on NDF digestibility in beef cattle that had free access to feed. However, ADF digestibility was significantly decreased by nitrate, which indicated that also in their study, fiber degradability did not remain completely unaffected. Better NDF degradation in the rumen and thus more fermentation, probably explains the numerically smaller decrease in $\mathrm{CH}_{4}$ per kilogram of DMI for cows on the $\mathrm{NO}_{3}+$ DHA treatment as compared with cows on the $\mathrm{NO}_{3}$ treatment (Table 3).

Table 6. Apparent total-tract digestibility of nutrients in lactating dairy cows fed the control $(\mathrm{CON})$ diet or diets with nitrate $\left(\mathrm{NO}_{3}\right)$, docosahexaenoic acid (DHA), or $\mathrm{NO}_{3}+$ DHA as feed additives

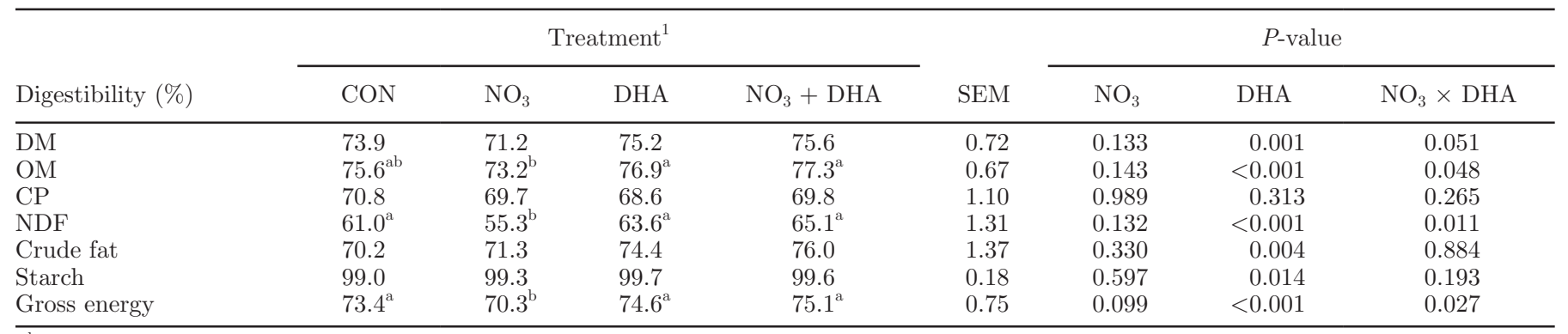

a,b Means within a row with different superscripts differ $(P<0.05)$.

${ }^{1} \mathrm{CON}$ (urea as nonprotein $\mathrm{N}$ source), $\mathrm{NO}_{3}\left(21 \mathrm{~g}\right.$ of nitrate $/ \mathrm{kg}$ of DM), DHA (3 g of DHA $/ \mathrm{kg}$ of DM and urea as nonprotein $\mathrm{N}$ source), $\mathrm{NO}_{3}+$

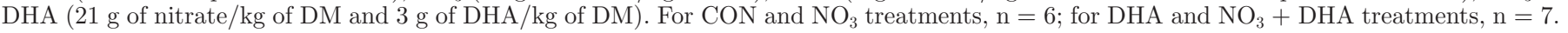




\section{CONCLUSIONS}

Additive $\mathrm{CH}_{4}$-mitigating effects, or a positive interaction, of nitrate and DHA fed together would have allowed for a significant decrease in $\mathrm{CH}_{4}$ at lower doses of individual additives. Feeding DHA strongly affected milk FA composition, but did not decrease $\mathrm{CH}_{4}$ production per kilogram of DMI and increased $\mathrm{CH}_{4}$ production per kilogram of FPCM, whereas nitrate showed a large and consistent decrease in $\mathrm{CH}_{4}$ production irrespective of the unit in which it was expressed. No interaction effect was found for the effects of nitrate and DHA on $\mathrm{CH}_{4}$ in grams per kilogram of DMI and $\mathrm{CH}_{4}$ in grams per kilogram of FPCM. A significant interaction effect between nitrate and DHA on NDF digestibility indicated that negative effects of nitrate on apparent total-tract digestibility of nutrients were alleviated by DHA. Such an interaction effect between nitrate and DHA could be of interest if nitrate is fed to decrease $\mathrm{CH}_{4}$ production, because a decrease in $\mathrm{CH}_{4}$ production should not be accompanied by reduced animal performance. Given the significant reductions in milk fat and protein yield by DHA and nitrate, respectively, the current doses of the additives are not recommended for application in practice.

\section{ACKNOWLEDGMENTS}

Abdulai Guinguina and Kitty Elsinghorst (Students of Wageningen University, the Netherlands) and the staff of the experimental facilities "Carus" (Wageningen, the Netherlands) are gratefully acknowledged for their assistance during the implementation of the experiment. This study is part of the Low Emission Animal Feed project. The authors acknowledge financial support of the Dutch Ministry of Economic Affairs (The Hague, the Netherlands), Product Board Animal Feed (Zoetermeer, the Netherlands), and the Dutch Dairy Board (Zoetermeer, the Netherlands), and acknowledge the TI Food and Nutrition project "Reduced methane emission of dairy cows" for providing milk fatty acid data.

\section{REFERENCES}

Boeckaert, C., V. Fievez, D. Van Hecke, W. Verstraete, and N. Boon. 2007. Changes in rumen biohydrogenation intermediates and ciliate protozoa diversity after algae supplementation to dairy cattle. Eur. J. Lipid Sci. Technol. 109:767-777.

Boeckaert, C., B. Vlaeminck, J. Dijkstra, A. Issa-Zacharia, T. Van Nespen, W. Van Straalen, and V. Fievez. 2008b. Effect of dietary starch or micro algae supplementation on rumen fermentation and milk fatty acid composition of dairy cows. J. Dairy Sci. 91:47144727.

Boeckaert, C., B. Vlaeminck, V. Fievez, L. Maignien, J. Dijkstra, and N. Boon. 2008a. Accumulation of trans C18:1 fatty acids in the rumen after dietary algae supplementation is associated with changes in the Butyrivibrio community. Appl. Environ. Microbiol. 74:6923-6930.

Brouwer, E. 1965. Report of sub-committee on constants and factors. Pages 441-443 in Energy Metabolism: Proc. 3rd Symp. K. L. Blaxter, ed. EAAP Publ. No. 11. Academic Press, London, UK.

Bruning-Fann, C. S., and J. B. Kaneene. 1993. The effects of nitrate, nitrite and N-nitroso compounds on human health: A review. Vet. Hum. Toxicol. 35:521-538.

Castro Montoya, J., A. M. Bhagwat, N. Peiren, S. De Campeneere, B. De Baets, and V. Fievez. 2011. Relationships between odd- and branched-chain fatty acid profiles in milk and calculated enteric methane proportion for lactating dairy cattle. Anim. Feed Sci. Technol. 166:596-602.

CVB. 2008. CVB Table booklet feeding of ruminants. CVB series no. 43. Centraal Veevoederbureau, Lelystad, the Netherlands.

Fievez, V., C. Boeckaert, B. Vlaeminck, J. Mestdagh, and D. Demeyer. 2007. In vitro examination of DHA-edible micro-algae 2. Effect on rumen methane production and apparent degradability of hay. Anim. Feed Sci. Technol. 136:80-95.

Grainger, C., and K. A. Beauchemin. 2011. Can enteric methane emissions from ruminants be lowered without lowering their production? Anim. Feed Sci. Technol. 166-167:308-320.

Guo, W. S., L. P. Ren, Z. M. Zhou, and Q. X. Meng. 2007. Difference of nitrogen contents determined by the combustion and Kjeldahl method in response to nitrate nitrogen in some feedstuffs. J. Anim. Feed Sci. 16:178-183.

Guyader, J., M. Eugène, B. Meunier, M. Doreau, D. P. Morgavi, M. Silberberg, Y. Rochette, C. Gerard, C. Loncke, and C. Martin. 2015. Additive methane-mitigating effect between linseed oil and nitrate fed to cattle. J. Anim. Sci. 93:3564-3577.

Hatew, B., J. W. Cone, W. F. Pellikaan, S. C. Podesta, A. Bannink, W. H. Hendriks, and J. Dijkstra. 2015b. Relationship between in vitro and in vivo methane production measured simultaneously with different dietary starch sources and starch levels in dairy cattle. Anim. Feed Sci. Technol. 202:20-31.

Hatew, B., S. C. Podesta, H. Van Laar, W. F. Pellikaan, J. L. Ellis, J. Dijkstra, and A. Bannink. 2015a. Effects of dietary starch content and rate of fermentation on methane production in lactating dairy cows. J. Dairy Sci. 98:486-499.

Hristov, A. N., J. Oh, J. Firkins, J. Dijkstra, E. Kebreab, G. Waghorn, A. Adesogan, W. Yang, J. Tricarico, C. Lee, P. J. Gerber, B. Henderson, and H. P. S. Makkar. 2013. Mitigation of methane and nitrous oxide emissions from animal operations: I. A review of enteric methane mitigation options. J. Anim. Sci. 91:5045-5069.

Hulshof, R. B. A., A. Berndt, W. J. J. Gerrits, J. Dijkstra, S. M. Van Zijderveld, J. R. Newbold, and H. B. Perdok. 2012. Dietary nitrate supplementation reduces methane emission in beef cattle fed sugarcane based diets. J. Anim. Sci. 90:2317-2323.

ISO. 1998. Animal feeding stuffs, animal products, and feces or urine. Determination of gross calorific value - Bomb calorimeter method. International Standards Organization, Geneva, Switzerland.

ISO. 1999a. Animal feeding stuffs. Determination of fat content. International Standards Organization, Geneva, Switzerland.

ISO. 1999b. Animal feeding stuffs. Determination of moisture and other volatile matter content. International Standards Organization, Geneva, Switzerland.

ISO. 2002. Animal feeding stuffs. Determination of crude ash. International Standards Organisation, Geneva, Switzerland.

ISO. 2004. Animal feeding stuffs. Enzymatic determination of total starch content. International Standards Organization, Geneva, Switzerland.

ISO. 2005. Animal feeding stuffs. Determination of nitrogen content and calculation of crude protein content-Part1: Kjeldahl method. International Standards Organization, Geneva, Switzerland.

Kil, D. Y., T. E. Sauber, D. B. Jones, and H. H. Stein. 2010. Effect of the form of dietary fat and the concentration of dietary neutral detergent fiber on ileal and total tract endogenous losses and apparent and true digestibility of fat by growing pigs. J. Anim. Sci. 88:2959-2967.

Lee, C., R. C. Araujo, K. M. Koenig, and K. A. Beauchemin. 2015a. Effects of encapsulated nitrate on enteric methane production, 
and nitrogen and energy utilization in beef heifers. J. Anim. Sci. 93:2391-2404.

Lee, C., R. C. Araujo, K. M. Koenig, and K. A. Beauchemin. 2015b. Effects of encapsulated nitrate on eating behavior, rumen fermentation, and blood profile of beef heifers fed restrictively or ad libitum. J. Anim. Sci. 93:2405-2418.

Lee, C., and K. A. Beauchemin. 2014. A review of feeding supplementary nitrate to ruminant animals: Nitrate toxicity, methane emissions, and production performance. Can. J. Anim. Sci. 94:557-570.

Lichtenwalner, R. E., J. P. Fontenot, and R. E. Tucker. 1973. Effect of source of supplemental nitrogen and level of nitrate on feedlot performance and vitamin A metabolism of fattening beef calves. J. Anim. Sci. 37:837-847.

Lund, P., R. Dahl, H. J. Yang, A. L. F. Hellwing, B. B. Cao, and M. R. Weisbjerg. 2014. The acute effect of addition of nitrate on in vitro and in vivo methane emission in dairy cows. Anim. Prod. Sci. 54:1432-1435.

Marais, J. P., J. J. Therion, R. I. Mackie, A. Kistner, and C. Dennison. 1988. Effect of nitrate and its reduction products on the growth and activity of the rumen microbial population. Br. J. Nutr. 59:301-313.

McAllister, T. A., and C. J. Newbold. 2008. Redirecting rumen fermentation to reduce methanogenesis. Aust. J. Exp. Agric. 48:7-13.

Moate, P. J., S. R. O. Williams, M. C. Hannah, R. J. Eckard, M. J Auldist, B. E. Ribaux, J. L. Jacobs, and W. J. Wales. 2013. Effects of feeding algal meal high in docosahexaenoic acid on feed intake, milk production, and methane emissions in dairy cows. J. Dairy Sci. 96:3177-3188.

Newbold, J. R., S. M. Van Zijderveld, R. B. A. Hulshof, W. B. Fokkink, R. A. Leng, P. Terencio, W. J. Powers, P. S. J. Van Adrichem, N. D. Paton, and H. B. Perdok. 2014. The effect of incremental levels of dietary nitrate on methane emissions in Holstein steers and performance in Nelore bulls. J. Anim. Sci. 92:5032-5040.

Rigout, S., C. Hurtaud, S. Lemosquet, A. Bach, and H. Rulquin. 2003. Lactational effect of propionic acid and duodenal glucose in cows. J. Dairy Sci. 86:243-253.

Rius, A. G., J. A. D. R. N. Appuhamy, J. Cyriac, D. Kirovski, O. Becvar, J. Escobar, M. L. McGilliard, B. J. Bequette, R. M. Arkers, and M. D. Hanigan. 2010. Regulation of protein synthesis in mammary glands of lactating dairy cows by starch and amino acids. J. Dairy Sci. 93:3114-3127.

Robertson, J. B., and P. J. Van Soest. 1981. The detergent system of analysis. Chapter 9, pages 123-158 in The Analysis of Dietary Fibre in Food. W. P. T. James, and O. Theander, ed. Marcel Dekker, New York, NY.
Shingfield, K. J., M. Bonnet, and N. D. Scollan. 2013. Recent developments in altering the fatty acid composition of ruminant-derived foods. Animal 7(Suppl. 1):132-162.

Spanghero, M., and Z. M. Kowalski. 1997. Critical analysis of N balance experiments with lactating cows. Livest. Prod. Sci. 52:113122.

Tamminga, S., W. M. Van Straalen, A. P. J. Subnel, R. G. M. Meijer, A. Steg, C. J. G. Wever, and M. C. Blok. 1994. The Dutch protein evaluation system-The DVE/OEB-system. Livest. Prod. Sci. 40:139-155

van Gastelen, S., E. C. Antunes-Fernandes, K. A. Hettinga, G. Klop, S. J. J. Alferink, W. H. Hendriks, and J. Dijkstra. 2015. Enteric methane production, rumen volatile fatty acid concentrations, and milk fatty acid composition in lactating Holstein-Friesian cows fed grass silage- or corn silage-based diets. J. Dairy Sci. 98:1915-1927.

van Lingen, H. J., L. A. Crompton, W. H. Hendriks, C. K. Reynolds, and J. Dijkstra. 2014. Meta-analysis of relationships between enteric methane yield and milk fatty acid profile in dairy cattle. J. Dairy Sci. 97:7115-7132

Van Soest, P. J., J. B. Robertson, and B. A. Lewis. 1991. Methods for dietary fiber, neutral detergent fiber, and non-starch polysaccharides in relation to animal nutrition. J. Dairy Sci. 74:3583-3597.

van Valenberg, H. J., K. A. Hettinga, J. Dijkstra, H. Bovenhuis, and E. J. M. Feskens. 2013. Concentrations of n-3 and n- 6 fatty acids in Dutch bovine milk fat and their contribution to human dietary intake. J. Dairy Sci. 96:4173-4181.

van Zijderveld, S. M., W. J. J. Gerrits, J. A. Apajalahti, J. R. Newbold, J. Dijkstra, R. A. Leng, and H. B. Perdok. 2010. Nitrate and sulfate: Effective alternative hydrogen sinks for mitigation of ruminal methane production in sheep. J. Dairy Sci. 93:5856-5866.

Van Zijderveld, S. M., W. J. J. Gerrits, J. Dijkstra, J. R. Newbold, R. B. A. Hulshof, and H. B. Perdok. 2011. Persistency of methane mitigation by dietary nitrate supplementation in dairy cows. J. Dairy Sci. 94:4028-4038.

Vlaeminck, B., V. Fievez, A. R. J. Cabrita, A. J. M. Fonseca, and R. J. Dewhurst. 2006. Factors affecting odd- and branched-chain fatty acids in milk: A review. Anim. Feed Sci. Technol. 131:389-417.

Vlaeminck, B., G. Mengistu, V. Fievez, L. de Jonge, and J. Dijkstra. 2008. Effect of in vitro docosahexaenoic acid supplementation to marine algae-adapted and unadapted rumen inoculum on the biohydrogenation of unsaturated fatty acids in freeze dried grass. J. Dairy Sci. 91:1122-1132.

Williams, C. H., O. Iismaa, and D. J. David. 1962. Determination of chromic oxide in feces samples by atomic absorption spectrophotometry. J. Agric. Sci. 59:381-385. 